\title{
URENHEDSFORESTILLINGER I DEN MONASTISKE KULTUR
}

\author{
Af Oluf Schönbeck
}

Jeg skal i det følgende give et bud på tolkningen af visse af de renhedsforestillinger, man finder i den vestlige middelalders monastiske kultur. Som det fremgår af denne publikations øvrige artikler, synes der at være en lang række fællestræk i de renhedsforestillinger, der optræder i mange kulturer, og det er min påstand, at min fortolkningsmodel også med udbytte kan anvendes på andet materiale end den kristne, europæiske middelalder. Modellen har altså et universelt sigte.

Efter en redegørelse for mit teoretiske grundlag og dets præmisser vil modellen blive appliceret på et tekstmateriale, og jeg vil afslutningsvis foretage en kortfattet opsummering.

\section{Teoretisk grundlag}

Mit teoretiske udgangspunkt er amerikaneme Georg Lakoff og Mark Johnsons arbejde med metaforer. ${ }^{1}$ Mere præcist er det Lakoffs bog, Women, Fire and Dangerous Things. What Categories Reveal About the Mind, der ligger til grund. Ifølge Lakoff er metaforer ikke kun stilistiske troper, som kan tjene til at forskonne eller variere sproget, men derimod et fundamentalt element i al sprogbrug og dermed også i sproglig tænkning. Mennesket tænker ifølge Lakoff ikke i små, afgrænsede enheder, men derimod i mør :re, gestalter, komplekser:

Thought is embodied, that is, the structures used to put together our conceptual systems grow out of bodily experience and make sense in terms of it; noreover, the core of our conceptual systems is directly grounded in perception, body movement, and experience of a physical and social character.. Thought is imaginative, in that those concepts which are not directly grounded in experience employ metaphor, metonymy, and mental imagery all of which go beyond the literal mirroring, or representation, of external reality. It is this imaginative capacity that allows for wabstractu thought and takes the mind beyond what we can see and feel. The imaginative capacity is also embodied --indirectly - since the metaphors, metonymies, and images are based on experience, often bodily experi- 


\section{Urenhedsforestillinger $\mathrm{i}$ den monastiske kultur}

ence. Thought is also imaginative in a less obvious way: every time we categorize something in a way that does not mirror nature, we are using general human imaginative capacities... Thought has gestalt properties and is thus not atomistic; concepts have an overall structure that goes beyond merely putting together conceptual sbuilding blocks" by general rules (Lakoff 1987, xiv).

Disse gestalter kalder Lakoff for kognitive modeller, der ligger til grund for og strukturerer en stor del af menneskets tænkning. Tænkning, der bygger på kognitive modeller, forstås ud fra modellens kropslighed (embodiment) og har altså sin oprindelse i kroppens interaktion med de fysiske omgivelser.

Ifølge Lakoff og Johnson er også abstrakt tænkning præget af en overføring af strukturer, der har deres oprindelse i den kropslige erfaring. En sådan overføring kalder Lakoff for en metafor, som defineres med henvisning til Austin:

When $A: B:: X: Y$ then $A$ and $X$ are often called by the same name, e.g, the foot of a mountain, and the foot of a list. Here there is good reason for calling the things both "feet " but are we to say they are "similare? Not in any ordinary sense. We may say that the relations in which they stand to $\mathrm{B}$ and $\mathrm{Y}$ are similar relations. Well and good: but $\mathrm{A}$ and $X$ are not the relations in which they stand (Austin, pp. 71-72). Austin isn't explicit here, but what seems to be going on is that both mountains and lists are being structured in terms of a metaphorical projection of the human body onto them. Expanding somewhat on Austin's analysis and translating it into contemporary terminology, we have:

$A$ is the bottom-most part of the body.

$\mathrm{X}$ is the bottom-most part of the mountain.

$\mathrm{X}^{\prime}$ ' is the bottom-most part of a list.

Body is projected onto mountain, with A projected onto X.

(Metaphor)

Body is projected onto list, with A projected onto $\mathrm{X}$ '.

(Metaphor)

The word "footu names A.

$A, X$, and $X^{\prime}$ form a category, with $A$ as central member. $X$ and $X$ ' are noncentral members related to $A$ by metaphor (Lakoff, 19f).

Som det fremgår af titlen på Lakoffs bog, beskæftiger han sig med de kategorier, hvori mennesket tænker, og ovenstående citat illustrerer, hvorledes en kategori (feet) er struktureret på grundiag af dels en fysisk, kropslig oplevelse 


\section{Oluf Schönbeck}

og dels en "metaforisering". Området, hvorfra modellen overføres, kaldes source domain (i dette tilfælde det menneskelige legeme); området, hvortil modellen overføres, kaldes target domain (i dette tilfælde bjerget eller listen). Selve overforingsprocessen kaldes source-target mapping.

Går vi ud fra, at mennesket tænker og oplever i kategorier, som er struktureret på baggrund af oplevelser, må det være relevant at spørge, hvad der kommer først: Oplevelsen eller kategorien, hvori oplevelsen er indlejret? Ræsonnementet synes at forudsætte en oprindelig, frrste erfaring uden for kategoriseringens struktur, og dette er da også tilfældet:

One of Mark Johnson's basic insights is that experience is structured in a significant way prior to, and independent of, any concepts. Existing concepts may impose further structuring on what we experience, but basic experiential structures are present regardless of any such imposition of concepts (Lakoff, 271).

Sâdanne førkategoriale erfaringsstrukturer eller basic experiental structures udmøntes i, hvad Johnson kalder image schemata, og danner grundlaget for bl.a. logisk tankning:

I would like to suggest...possible experiential bases for some logical connectives and inferiental structures. In particular, I want to suggest that image schemata constrain inferences (and thus reasoning) in certain basic and important ways. They an do this because they have definite internal structure that can be figuratively extended to structure our understanding of formal relations among concepts and propositions (Johnson 1987, 38).

Implikationen af dette synspunkt synes at være, at der før, $b: y$ eller under (for nu at bruge et par rummetaforer) forskellige kulturers unc ertiden meget forskellige kategorier findes en oprindelig, universel, førkategorial oplevelse baseret på kroppens fysiologiske struktur, og dette er da også den afgørende præmis for mit postulat om min fortolkningsmodels universelle anvendelighed. Når forskellige kulturers menneskeskabte kategorier undertiden synes at afvige temmelig meget fra hinanden, må dette altså forklares som en varierende bearbejdning af fælles, førkategoriale oplevelser begrundet i fx forskellige økologiske forudsætninger. 


\section{Urenhedsforestillinger i den monastiske kultur}

Image scemata (Johnsons term) eller kinesthetic image schemas (Lakoffs term) er altså kognitive modeller, der inkorporerer en fysisk-kropslig erfaring af bevægelse, rum og grænser. Lakoff opregner en lang rakke af sådanne image schemas: The Link Schema, The Center-Periphery Schema, The Source-Path Schema, Up-Down Schema, Front-Back Schema, Linear Order Schema etc. I sine case studies behandler og eksemplificerer Lakoff disse skemaer udførligt, men jeg skal begrænse mig til et enkelt kinesthetic image schema, nemlig The Container Schema, som ud over at være særdeles udbredt også synes mig særligt anvendeligt til analyse af renheds-/urenhedsforestillinger. Stillet op skematisk fremtræder container-modellen således:

The Container Schema

Bodily experience: As Johnson points out, we experience our bodies both as containers and as things in containers (e.g., rooms) constantly.

Structural elements: INTERIOR, BOUNDARY, EXTERIOR.

Basic logic: Like most image schemas, its internal structure is arranged so as to yield a basic "logic". Everything is either inside a container or out of it - $P$ or not $P$. If container $A$ is in container $B$ and $X$ is in $A$, then $X$ is in $B$-.. which is the basis for modus ponens: If all $A$ 's are $B$ 's and $X$ is an $A$, then $X$ is a B...

Sample metaphors: The visual field is understood as a container, e.g., things come into and go out of sight. Personal relationships are also understood in terms of containers: one can be trapped in a marriage and get out of it. (Lakoff, 272) ${ }^{2}$

De kognitive modeller skabes altså $\mathrm{i}$ et vekselspil mellem mennesket som et biologisk væsen og dets fysiske omgivelser. Når børn lærer ord, vil indlæringsprocessen altid indeholde handlingsaspekter. Man plasker i vandet, klapper hunden, snuser til blomsten, lytter i telefonrøret, drejer på stereoanlæggets knapper etc. Ordene indlejres i kognitive modeller, som indeholder en erfaring af orientering og bevægelse i rummet. Kognitive modeller kan være af en sådan karakter, at de kan overføres til andre områder end den konkrete, fysiske situation, hvorunder de er dannet. Sådanne kognitive modeller kaldes metaforer. Hertil kommer, at kognitive modeller kan interagere indbyrdes eller kan indlejres i hinanden. 


\section{Oluf Schönbeck}

Jeg skal i det følgende foreslå en sådan indlejring til belysning af renhedsforestillinger, men først et par ord om kroppen som container. Som nævnt indeholder denne containermodel tre essentielle elementer: Et indre, en overflade $o g$ et ydre. Denne menneskelige krop har et indre rum, der er delvist fyldt op af kropsvasker og organer. Delvist, fordi vi kan fylde fx mad og drikke $\mathrm{i}$ den. Kropsvæskerne og de indre organerne holdes på plads af overfladen, huden, som er særdeles skrøbelig. Blot den mindste rift slipper kropsvæske ud. Et større hul vil, såfremt det ikke lukkes, medføre en større udtømning, evt. med døden til følge. Uden for kropscontaineren befinder sig det sociale og ekologiske rum med dets tilsyneladende uendelige udstrakning. Vores hud udgør den skrøbelige grænse mellem os som individer og de undertiden meget farlige omgivelser, som kan trænge ind i os, såfremt vores afgrænsende overflade nedbrydes. Læsioner kan altså medføre såvel farlig udtømning som farlig indtrængen. Fra naturens side er vores overflade forsynet med syv åbninger (ni, hvis vi tæller øjnene med; otte hvis næseborene tælles som een åbning). Også disse åbninger tillader udtømning og indtrængen af potentiel skadelig art, hvorfor de forståeligt nok omfattes af en vis opmarksomhed. Vores overflade kan dækkes af forskelligt materiale, som kan fjernes igen med større eller mindre lethed. Denne tildækning kan tjene forskellige formål men også være utilsigtet $\mathrm{og}$ uønsket og ligefrem farlig.

Det forekommer mig, at visse af de urenhedsforestillinger, der optræder $i$ middelalderens monastiske litteratur, kan forstås på baggrund af to grundlæggende erfaringer:

I) Sygdom eller legemlig beskadigelse med smerter og dysfunktion til følge.

II) Misfarvning af eller belægning på huden.

Begge disse erfaringer kan ses som indlejret i den mere fundamentale model, The Container Schema. Sygdom og legemsbeskadigelse er eksempler på, at containerens overflade er blevet nedbrudt eller ikke har opfyldt sin funktion, nemlig at opretholde grænsen mellem containerens indre og ydre, med livstruende udtømning eller indtrængen til følge. Containerens overflade kan imidlertid også være blevet tildækket af et materiale, som anses for livstru- 


\section{Urenhedsforestillinger i den monastiske kultur}

ende eller skadeligt. Dette materiale kan undertiden fjernes ved hjælp af vand eller andre væsker.

\section{Asketens urenhedsforestillinger}

Teksteksemplerne, som vil blive søgt fortolket ved hjælp af denne containermetafor, er primært hentet fra et brev skrevet omkring år 1060 af den italienske munk, Petrus Damiani, og stilet til Blanca, tidligere grevinde, nu nonne. ${ }^{3}$ Brevet er udformet dels som en lovprisning af det skridt, som Blanca har taget ved at blive Kristi brud, dels som en vejledning i, hvordan hun bedst kan forblive i denne sin nye stand.

Efter at have beskrevet Blancas bryllup med Kristus i overdådige vendinger, hentet fra Esajas' Bog, går Damiani over til at sammenligne det med brylluppet i Kana. Dér var Kristus til stede som gæst, mens han hér deltager som selve brudgommen. Om Blancas højtidelige bryllup skriver Damiani:

Og eftersom den, der binder sig til Herren, er én ånd med ham [1 Kor 6, 17], knytter gommen sig ikke blot til denne brud, men forenes med hende, og der fødes ikke fordarv af denne forening, men snarere gendannes jomfruelighedens segl. ${ }^{4}$

Det centrale ord i denne sammenhæng er fordærv, corruptio, som spiller på to betydninger. I overført betydning henviser det til den siden Augustin herskende forestilling om videregivelsen af arvesynden gennem den seksuelle forplantning, concupiscentia. I bogstavelig betydning henviser substantiveringen af verbet corrumpo, at rive i stykker, til ødelæggelsen af hymen i forbindelse med kærlighedsakten. Ved sin aflæggelse af klosterløftet har Blanca forpligtet sig til at leve i kyskhed, hvorfor Damiani med en vis ret kan sige, at jomfrueligheden er gendannet. Den egentlige betydning af ordet integritas, der her optræder som modsætning til corruptio, er imidlertid helhed, her også kroppens helhed, som er blevet ødelagt ved samlejet (Blanca havde en søn). Ødelæggelsen af kroppens overflade (hymen) har i Damianis øine medført en moralsk urenhed (corruptio).

Stadig inspireret af fortællingen om brylluppet i Kana fokuserer Damiani herefter på vinen, som Jesus ved sit under har tilvejebragt. Den sande vin er imidlertid Gud eller Guds ånd (Damiani refererer her implicit til forvandlingen i sakramentet), som beruser mennesker i en sådan grad, at de bliver som 


\section{Oluf Schönbeck}

fremmede for sig selv og af omgivelserne bedømmes som fulde, gale eller besat af dæmoner:

Hvilket under er det da, hvis disse mænd, som er rene, når de fyldes af Guds Ånd, af denne verdens kloge regnes for gale, hvorved de ger sig selv til tåber, når selv han, som er englenes Herre, siges, at have været besat af en dæmon? ${ }^{s}$

Denne sobria ebrietas, adru beruselse, som er et topos i den kristne tradition og formentlig går tilbage til endnu ældre, mystiske traditioner, sættes lig med renhed og fremkommer ved, at mennesket fyldes, repleo, med Guds ånd, spiritus Dei, i modsætning til, når det fyldes med druens ånd, spiritus vini. Det er med andre ord ikke alle indtrængende substanser, der af Damiani regnes for skadelige eller forurenende.

Ud over at beruse mennesket med Guds ånd har blodet $\mathrm{i}$ form af den forvandlede vin også den funktion, at den renser mennesket. Når Jesus i Højsangen 5,10 ifølge Damiani beskrives som hvid og rød, forklarer han det med, at Jesus kaldes "Rød, som Johannes siger om ham, fordi han har afvasket vore synder med sit blod " [Åb 1,6. Min oversættelse af Vulgata]. ${ }^{6}$ Synden beskrives her som en form for forurening, der kan afvaskes, laveo, på samme måde som man med vand vasker mudder eller støv af huden, kroppens grænseflade.

Det vil formentlig ikke overraske nogen, at denne religiøse virtuosus, der som prior for et semi-erimitisk kloster var en engageret fortaler for et stærkt asketisk liv, i særlig grad var optaget af, hvad der bevægede sig ind gennem sansernes naturlige kropsåbninger, der sammenlignes med frelserens fem sår:

Det er sandelig ikke tilfældigt, at disse [forløserens săr] er fem, nemiig lansens og naglernes, for da vi var blevet såret med de fem sansers sår, er den evige ielse atter blevet givet os gennem disse fem sår. ${ }^{\text {? }}$

Frelseshistorisk refererer denne sammenligning selvfølgelig til menneskets forløsning gennem Kristus' sonoffer på korset; men samtidig gør det omvendte ræsonnement sig gældende, nemlig at lige som Kristus døde som følge af blodet, der løb ud gennem hans sår, står mennesket $i$ fare for at miste sin sjæl og det evige liv på grund af de ting, der trænger ind gennem sanseåbningerne, såfremt det ikke passer på. Denne legemlige og sjælelige dobbelthed kommer til udtryk i ordet salus, der både betyder helse og frelse. 


\section{Urenhedsforestillinger i den monastiske kultur}

Efter at have lovprist Blanca for hendes beslutning om at indtræde $\mathrm{i}$ klostrets fællesskab benytter Damiani lejligheden til at advare hende mod de problemer, der uvægerligt vil opstå i hendes nye liv. Som erfaren munk ved han, at en nyindtrådt ofte vil føle sig fristet af minder om sit tidligere liv til at forlade klostret og vende tilbage til verden. Som modgift mod sådanne fristelser anbefaler han regelmæssig meditation over den forfærdelige død, der venter en synder, for slet ikke at tale om straffen på Dommens Dag. Pă denne dag skal alting vendes op og ned, de ydmyge skal oprejses, og denne verdens store og magtfulde skal nedkastes. Visse af sine billeder henter Damiani fra Esajas' Bog, hvor denne verdens høje, knejsende, ophøjede og stolte bl.a. kaldes "Basans ege" (Es 2,13). Ud over at være høje og imponerende har denne verdens fyrster og Basans ege også det til fælles, at de $\mathrm{i}$ bund og grund er ufrugtbare: Denne verdens fyrster med hensyn til gode gerninger, og Basans ege med hensyn til deres frugt, agern, som er uegnet til menneskeføde og kun duer til at fordre svin med. Disse svin fortolker Damiani allegorisk på følgende måde: "Men svinene skal forstås som urene ånder, der spiser sig fede $\mathrm{i}$ urene menneskers smudsige gerninger. $\mu^{8}$

Den forurenende substans er her menneskers smudsige handlinger, ud fra konteksten mere specifikt verdens fyrsters, som nærer og optages af de urene ånder, fra hvem de videregives til enhver, der er uforsigtig nok til at lytte til dem:

Thi som en fugl på træets gren sidder den onde ånd ofte på smigerens tunge, og giften strømmer ligesom gennem kroppens organ ind i kroppen og gennemtrænger på dræbende vis den lyttendes indre. ${ }^{9}$

Hvor konkret og virkelig denne metaforisering, denne analogi, mellem det legemlige og det sjælelige er for Damiani, fremgår af folgende citat vedrørende en af munkene $i$ hans kloster, Fonte Avellana, som efter at have levet et eksemplarisk, kysk liv i næsten otte år og have kopieret mange skønne bøger i klostrets skriptorium pludseligt forandrede sig:

Men for nylig, da han syntes kraftigere og mere rund og stark end sadvanlig, begyndte han stædigt at kræve at fă lov til at vende tilbage til sit [gamle] kloster. At det utvivisomt var den onde modstander, der indgav hans hjerte denue lyst, fremgår klart af, hvad der siden skete. For snart, da han efter sit ønske var vendt tilbage til sit kloster, syndede han 


\section{Oluf Schönbeck}

kødeligt med en anden skændig, gammel munk, som ligeledes var en dygtig skriver og bibliotekar, således at han med denne mest skændige forbrydelses pludselige smitte besudlede det rene liv, han lange havde levet. $\mathrm{Og}$ for at ikke sådan synd skulle forbigås uden fortjent straf, blev han kort efter syg og døde få dage senere med uroligt sind efter at have skriftet. ${ }^{10}$

Det er altså djævelen, der har indgivet, infero, munken de urene tanker, som forårsager en andring i hans ydre, der $i$ et eremitisk fællesskab stærkt præget af askese og faste naturligvis må vække mistanke. Da han vender tilbage til sit tidligere kloster, har den gamle skriver formentlig straks kunnet se, at her var en munk, der ikke ville være uimodtagelig for hans tilnærmelser. De indleder et forhold, som medfører en sædudtømmelse, femoralis fluxus egestio, der viser sig at få dødelige konsekvenser. Hele historien om munkens moralske fald har med andre ord form af et drama om forskellige substansers passage ud og ind gennem kroppens overflade, der ændrer karakter i takt hermed. Motivet er et eksempel på, hvor galt det kan gå, dersom det menneskelige legeme ikke beskyttes med tilstrækkelig nidkærhed mod de farer, der omgiver det og konstant truer med at invadere det.

\section{Om renselse}

Har forst forureningen fundet sted, står forskellige renselsespraktikker til rådighed. Er giften trængt ind gennem en kropsåbning, fx øret, kan den udtømmes igen ved hjælp af et opkastningsmiddel, en modgift i form af ovennæunte meditation over døden og Dommens Dag:

\footnotetext{
Men du, min frue....brr ofte gennemlase disse og lignende ting vedrør ade Guds vrede og forbitrede harme, som kan ses at vente dem, der elsker denne v 2 rc ^n, og noje overveje dem, for at du derved ligesom med en bitter modgift kan undvige aen gamle slanges hvislen og hans dræbende gift. For jeg selv har ofte oplevet, når mine indvolde var gennemtrangt af disse tankers bitterhed, at mit sirzds mave - for nu at sige det sådan tommes for aiverdens smigers væsker. ${ }^{\text {I }}$
}

Forureningen er altså ikke en irreversibel proces. Den rette modgift kan vende forløbet og forårsage en udtømning af den forurenende substans. Ud over meditation anbefaler Damiani også svøben, dels som et bodsmiddel, hvormed en synder påtager sig rollen som sin egen dommer og bøddel, og dels som et 


\section{Urenhedsforestillinger i den monastiske kultur}

middel til at ave kroppen og til imitatio Christi: ${ }^{12}$ "Pas blot på ikke at hvile i kødets forkælelse, men gør dig årvågent umage med den hellige svøbe. $\alpha^{13}$

Som antydet var Damiani en varm fortaler for alle former for askese, men for eftertiden står han især som den, der mere end nogen anden medvirkede til udbredelsen af brugen af pisken som bodsmiddel også blandt lægfolk: ${ }^{14}$ "...så meget har derfor...denne svøbens brug bredt sig i vore egne, at ikke blot mænd, men også adelige kvinder ivrigt griber til denne form for renselse. ${ }^{15}$

I Damianis øjne har alle bodsmidler til formål at rense kroppen for urenhed: "For uanset med hvilket bodsmiddel kødet lemlæstes og slås, så renser det utvivlsomt mennesket for den smuds, det har pådraget sig gennem sin skyld. « ${ }^{16}$

De øvrige ovenfor nævnte renselsesmidler virkede enten som vaskemidier (blod, vand) eller som opkastningsmiddel (meditation), det vil sige med udgangspunkt i containermetaforen. Hvorledes med svøben? Ganske vist anvendes den på kroppens overflade, men hvorledes kan den siges at rense kroppen for urenhed? Damiani selv giver ingen forklaringer, men vender vi os til et af den middelalderlige litteraturs hovedværker, nemlig Gregor den Stores Dialoger, finder vi i Bog II omtalt, hvordan Benedikt af Nursia, mens han endnu levede i sin hule ved Subiaco, fristes af djævelen, der får ham til at tæanke på en kvinde, han engang har set. I en sådan grad rives han med af sit begær, at han er lige ved at opgive sit eneboerliv:

Da kom han pludselig ved Guds nåde til sig selv, og idet han ved siden af sig så et tæt krat af nælder og tomebuske, flåede han sit tøj af og kastede sig nøgen blandt de spidse torne og brændende næìder; efter at have rullet sig så længe dér, at hele hans krop var fuld af sår, rejste han sig og ledte dermed sindets sår ud gennem hudens sår, idet han med smerten besejrede vellysten. ${ }^{17}$

Her er ganske vist ikke tale om en egentlig svøbe, men princippet er det samme, og da Damiani med stor sikkerhed kan formodes at have kendt dette locus classicus, er det nærliggende at tro, at han har tænkt i lignende baner. Ved en kontrolleret blodudtømning kan legemet renses for farlige substanser, en model, der har nydt stor udbredelse i den vestlige verdens medicin i form af åreladning. 
Som tidligere nævnt kan metaforer interagere eller indlejres $i$ hinanden - et eksempel på, hvad Lakoff kalder creative thinking - og vender vi tilbage til Damiani, finder vi da også, at der i de forestillinger, han knytter til svøbens brug, indgår flere modeller, som alle i en eller anden forstand knytter an til dens brug som renselsesmiddel. Her skal blot anføres to yderligere eksempler. I et af sine breve forsvarer Damiani sig mod kritik af hans anbefaling af svøben som bodsmiddel på bl.a. følgende måde:

Hvorfor undre sig, hvis kødet, som, năr det blev forkælet, ledte os i eksil, omvendt fører os tilbage til fadrelandet, når det plages? Og hvis vi med det samme, hvormed vi tidilgere syndede $\mathrm{i}$ vores fordarvelige eftergivenhed, forbedrer os i vores frelsende revselse, eller, for at sige det sådan, hvis dyret, som nu er tæmmet [egl. giort ydmygt], bærer det kvastede menneske, som det først i sin utålmodighed sanseløst og afsindigt har sparket, til den heibredende lage? ${ }^{18}$

Legemet beskrives her som en hest eller et muldyr, der efter at være blevet tæmmet med pisken, må bære sin kvæstede rytter, dvs. sjælen, till lægen, dvs. Gud. Hvor dybt renselsesprocessen er indlejret i en "medicinsk" metaforik, fremgår af følgende citat, hvori Damiani takker Gud for at have bragt ham frelst igennem en alvorlig sygdom, ja endog for at have påfort ham den:

Som jeg sagde, takker jeg dig, barmijertige Gùd, fordi du - da jeg under mine synders brokker fortjente at rives bort til straffen - fandt mig værdig at lutres $\mathrm{i}$ din faderlige strengheds ild og min sjæls rust værdig at bortrenses som ved hammerens slag. Dog ske ikke min vilje, Gud, som altid er ond og uretfærdig, men hellere din, som bør tilbedes af himlens magter og mennesker. Brænd, skær og amputér, og gennemsøg alle mine sårs folder og krinkelkroge. Og da skal ingen råddenskab, som undgår din undersøgelses kniv, skjule sig i mig. Dog, Gud forbyde, at jeg tilskriver den sindsro, hvor' ied jeg udstår den himmelske svøbes slag, min tälmođighed. Sandelig, Herre, når du sl. r, tilpasser du dit svøbeslag således, at jeg - idet jeg når den højeste smerte og trængsel, og năr jeg udsættes for krampetrækningen og næsten tvinges til snart at udånde -. straks foler, at den in tense smertes vagt er mindsket, og hånden, der slår, er standset ved en styrelsens mildhed, som om nogen holder en pisk med fire remme for at slå og styret af medfølelse holder en af piskens remme tilbage fra slaget. ${ }^{19}$

Gud er således lægen, der med sine instrumenter, ild og kniv, hvis brug manifesteres i menneskets lidelse og helbredelse, renser det for det urene, putridus. Det syndige menneskes tilstand beskrives som en tilstand af sygdom, der 


\section{Uremhedsforestillinger i den monastiske kultur}

diagnosticeres som en forurening af menneskelegemet. Den egentlige forureningskilde er Damianis synder, peccati, der formentlig er indgivet ham af djævelen, jf. ovenfor.

Belønningen for at have holdt sig ren eller have gennemført tilstrækkelig renselse vil til sin tid komme i form af en invitation til at deltage i det himmelske gastebud, der fremstår som højdepunktet af renhed:

Og dér skal ydermere sjæælen [egl. den menneskelige natur] danse, som var ufuldkommen, men nu er renset for alle lidenskabers smuds, og renset skal den forblive i sin ubesudlede og ufordærvede renhed. ${ }^{20}$

For Damiani og hans asketer var menneskekroppen altid mere eller mindre uren. Ganske vist indeholdt deres kristne religion en lang rakke renselsespraktikker, fx renselse ved vand i dåben, renselse ved Kristus' blod i nadversakramentet, konfessionens sakramente (en mundtlig form for udtømning), exsorcisme og en lang række bodsformer, og alligevel var de til stadighed nødt til at være årvågne (også i form af vågen og faste) og påpasselige over for alle skadelige substanser, der truede med at invadere dem i bogstavelig eller overført forstand. ${ }^{21}$ De hengav sig efter ørkenfædrenes eksempel til utallige former for askese eller kropspraktikker, der alle havde form af kropskontrol, dvs. kontrol af alt, der passerede ind og ud gennem kroppens naturlige åbninger. Det var en del af deres verdensforståelse, at liget af et menneske, der til fulde havde formået at praktisere denne kontrol, dvs. en helgen, duftede sødt og ikke gik i forrrådnelse. For et menneske, der havde hengivet sig til kødets glæder, var det modsatte tilfældet:

Betænk altså, at legemet, som nu nares ved lækre retter, snart vil vrimle med orme og seiv blive rotters føde; at det, som nu glædes over at blive fyldt med fin mad, skal udsende en tung stank af forrådnelse i samme grad, som det er blevet opdraget til luksus. ${ }^{22}$

\section{Sammenfatning}

Damianis beskrivelse af religiøs urenhed er domineret af et billedsprog, som $\mathrm{i}$ udstrakt grad er hentet fra en "medicinsk" diskurs. Det religiøst urene menneske (a) beskrives som såret eller smittet, og beskrivelsen af en sådan patologisk tilstand (b) er igen struktureret over den mere generelle oplevelse af 
menneskekroppen som en beholder eller container (c), hvis overflade (huden) ikke i tilstrakkelig grad har formået at holde skadelige substanser ude. Beskrivelsen fungerer altså på tre niveauer, der er indlejret $\mathrm{i}$ hinanden, og vi er nu i stand til at beskrive den form for source-target mapping, der karakteriserer Damianis urenhedsforestillinger:

Source domain: Kroppen som container bestående af et indre, en overflade og et ydre rum. Dette er en basal oplevelse eller basic experiental structure, der projiceres på følgende target domain:

Target domain: Sygdom eller legemlig beskadigelse med smerter og dysfunktion til følge. Misfarvning af eller belægning på huden. Sådanne fænomener fortolkes med udgangspunkt $\mathrm{i}$ oplevelsen af kroppen som container, og disse fortolkninger overføres derefter til følgende target domain:

Target domain: Religiøse urenhedsforestillinger.

Damianis religiøse urenhedsforestillinger kan dermed ses at være indskrevet $i$ en kroppens diskurs. En mere omfattende undersøgelse end den foreliggende ville formentlig vise, at hele Damianis religiøse forestillingsverden på lignende vis kan demonstreres at tage udgangspunkt i kroppens interaktion med omverden. Det er nærliggende tentativt at karakterisere religiøse forestillinger som metaforiske projektioner af basale, kropslige erfaringer Imidlertid er processen jo dialektisk, idet metaforerne atter indvirker pí ce kropslige erfaringer, jf. Lakoff: "Existing concepts may impose further structuring on what we experience, but basic experiential structures are present regardless of any such imposition of concepts." (Lakoff, 271)

En religiøs forestillingsverden kan - i lighed med andre abstrakte systemer som fx formel logik - med andre ord ses som et produkt af menneskets kreative tænkning, hvormed basale, fysiologiske erfaringer projiceres på fæænomener, der udviser en lignende relationel struktur. ${ }^{23}$ Set $i$ et videre perspektiv er det ikke overraskende at finde en kulturs værdier afspejlet $i$ bl.a. synet på kroppen. Mere overraskende er det måske, at processen også găr den 


\section{Urenhedsforestillinger i den monastiske kultur}

modsatte vej, nemlig at kropsoplevelsen afspejles i ideologien, hvorfor min pointe da også har været at påpege det forhold af dynamisk dialektik, der synes at bestå mellem krop og ideologi.

\section{Noter}

1. Lakoff $1987 \mathrm{og}$ Johnson 1987.

2. Som det fremgår af dette skema, benytter Lakoff lingvistisk materiale, sprogbrug, i sin undersøgeise af menneskets kognitive egenskaber, hvilket naturligvis forudsætter en overensstemmelse mellem sprog og tanke: "At this point I will adopt as a working hypothesis that language does make use of general cognitive mechanisms - at least categorization mechanisms, (Lakoff, 67). Den samme pramis galder naturligvis for min undersøgelse.

3. Brevet kan findes som nr. 66 i Reindel 1988. En engelsk oversattelse findes i Blum 1992.

4. "Et quoniam, qui adheret Domino, unus spiritus est, sponsus iste non modo sponsae iungitur, sed unitur, atque ex hac copula non corruptio nascitur, sed integritatis potius clausula reparatur." (Reindel, 249). Hvor intet andet er anført, er artiklens forfatter ansvarlig for oversattelserne. Dette gxider dog ikke bibelske citater, der - medmindre andet specifikt er anført - er taget fra den autoriserede danske oversættelse.

5. "Quid autem mirum, si bii, qui puri sunt homines, cum spiritu divino replentur, ab huius mundi sapientibus atque ideo vere desipientibus iudicentur insani, cum et ipse, qui magister est angelonum, dictus sit habuisse demonium?" (Reindel, 250). Jf. i øvrigt SI 103,15; Sl 22,5; Ap G 2,13; 2 Kong 9,11; Joh 8,48-52; Mark 3,20-21.

6. "Rubicendus, de quo Iohannes dicit, quira lavit nos a peccatis nostris in sanguine suo," (Reindel, 257).

7. "Quae profecto non casu quinque sunt [vulnera redemptoris], lancae scilicet et clavorum, sed quia nos fueramus quinque sensuum vulneribus sauciati, per has quingue plagas saluti sumus perpetuae restituti. (Reindel, 253). Ifølge Dressler 1954, 210, finder man hos Damiani det måske tidligste eksempel på en begyndende tilbedelse af Kristus' fem sår.

8. "Sues autem inmundi intelligendi sunt spiritus, qui spurcis sordentium hominum operibus saginantur." (Reindel, 265).

9. "Sepe enim malignus spiritus velut avis in ramo arboris sic in lingua ponitur adulantis, et tamqquam per organum vasis in vasi virus effluit, quod loetaliter in audientis interiora transfundit " (Reindel, 266).

10. Nuper autem, cum obeso vigetus corpore ac robustior solito videretur, coepit obstinate deposcere, ut ad summ permitteretur monasterium remeare. Quod nimirum malignus cordi eius intulit adversarius, aut perspicue postmodum ipsius rei declaravit eventus. Nam mox, ut iuxta petitionem ad suum monasterium est reversus, cum alio quodam monacho dienum malorum sene litteris aeque perito atque librario per femoralis fluxus egestionem cecidit, sicque omne, quod mundus diutius vixerat, repentina sceleratissimi criminis contagione 


\section{Oluf Schönbeck}

foedavit. Neve sine vindicta tam plectibilis culpa transiret, aegritudine mox irrudente decubuit paucisque deinceps diebus ex hac vita confessus et confusus exivit. "(Reindel, 267).

11. "Tu autem, domina mea...tu itaque haec et his similia, quae de divini furoris et indignationis amaritudine mundi leguntur amatoribus imminere, crebrius perlege, suptiliter meditare, ut hoc velut amarae confectionis antidoto sibilos antiqui serpentis eiusque loetale virus possis evadere. In memetipso quippe frequenter expertus sum quia, cum visceribus meis huius cogitationis amaritudo diffunditur, a cunctis male blandientis mundi, ut ita loquar, humoribus mentis meae stomachus exiccatur. "(Ibid.).

12. Jf. Reindel, brev 45, 34-39, samt brev 56, 153-161.

13. "Cave tantummodo, ne in carnis mollicie requiescas, sed in sanctae disciplinae laboribus te vigilanter exerceas. " (Reindel, 274).

14. If. Coln 1962, isar afsnittet "The genesis of the flagellant movement" (124-135), hvis kilder bl.a. er to af Damianis værker, samt Louis Gougaud, der i sin Dévotions et Pratiques Ascétiques du Moyen Age skriver: "Saint Pierre Damien...fut incontestablement le grand promoteur de la discipline au XIe siècle." (181).

15. "... itaque... faciendae disciplinae mos adeo in nostris partibus inholevit, ut non modo viri sed et nobiles mulieres hoc purgatorii genus inhianter arriperent. (Reindel, 276).

16. "Quodcumque enim illud est, per quod caro paenitenciae causa laceratur atque percellimr, per hoc homo proculdubio contracti reatus squalore purgatur." (Reindel, brev 56, 159).

17. "Cum subito superna gratia respectus ad semetipsum reversus est, atque urticaram et veprium juxta densa succrescere fruteta conspiciens, exutus indumento nudum se in illis spinarum aculeis et urticarum incendiis projecit: ibique diu volutatus, toto ex eis corpore vulneratus exiit, et per cutis valnera eduxit a corpore vulnus mentis; quia voluptatem traxit in dolorem." (Migne, PL, LXVI, $132 \mathrm{BC}$ ).

18. "Quid enim mirum, si caro, quae nos in exilium leta deiecit, versa vice ad patriam afflicta reducit? Et per hoc idem, cui dudum noxie consentiendo peccavimus, idipsum nunc castigando salubriter emendemus, atque, ut ita loquar, eadem bestia iam humilis facta curandum medico collisum hominem vehat, quem primitus infrunita atque vesaniens inpatienti calce percusserat? " (Reindel, brev 45, 39).

19. "Gratias, inquam, ago tibi misericors Deus, quia cum dignus fuerim sub peccatorum meorum ruderibus ad supplicium rapi, dignatus es me paternae saeverita' i igne decoquere, et animae meae rubiginem tamquam malle cudentis impactione pur yar. . Quamobrem non mea voluntas fiat, Domine, quae prava semper est et iniusta, seci tua potius, quae caeli virtutibus et hominibus est humiliter adoranda. Ure, seca, concide, omnesque vulnerum meorum sinus ac latebras perscrutare. Nichilque prorsus in me leteat putridum, quod curationis tuae praetervolet ferramentum. Nec tamen dum hos discipliniae caelestis ictus aequanimiter fero, meae patientiae, quod absit, adscribo. Tu nimirum, Domine, tu sic flagella tua, dum cedis, attemperas, ut dum ad summum doloris et angustiae perferor, ita ut spasmum patiens pene mox expirare compellar, ilico sentiam pondus intimi doloris imminui, et cedentis manum dispensativa quadam lenitate suspendi, ut tamquam quadrifidam quis scuticam in verbere teneat, et interim pietate ductus unum ex his lorum a cede compescat, " (Reindel, brev 55, 150). 


\section{Urenhedsforestillinger i den monastiske kultur}

20. "Ibi praeterea natura humana, quae viciata fuerat, cunctis passionum squaloribus defaecata tripudiat, et azima facta in suae puritatis atque sinceritatis mundicia perseverat." (Reindel, 278).

21. Til grund for enhver renselsesforestilling iigger formentlig et kinesthetic image schema, som man kunne kaide the carrier schema, og som i en vis forstand også kan siges at vare indlejret i the container schema. Dette image schema indeholder en erfaring af at indopta ge eller at forbinde sig med en genstand, som derefter kan flyttes fra et punkt til et andet punkt og dér blive udtøint eller frigjort. Det er dets egenskab af at kunne fungere som carrier, der gør vand så eftertragtet som religiøst renselsesmiddel, hvorfor der da også i almindelighed foretrakkes rindende vand. Den samme egenskab har også andre væsker, fx blod, men generelt gælder det, at de fleste ting kan fungere som carriers, når blot de kommer i berøring med det, der ønskes flyttet. Har den pågæidende carrier en eller anden form for lighed med det, der onskes fjernet, sker optagelsen eller indgås forbindelsen så meget desto lettere. Det er muligvis den samme kognitive model, der udgør princippet for den homøopatiske medicin, og som udtrykkes i vendingen mmed ondt skal ondt fordrives«: Hvad der har bragt noget, må også kunne fjerne det. Dette kan måske også forklare, hvorfor den forurenende substans undertiden kan indgå som aktivt middel i renselsesritualer.

22. "Perpende igitur, quia caro, quae nunc accuratis dapibus enutritur, paulo post vermibus scaturire compellitur, ipsaque fit tunc esca rodentium, quae nunc delectabiliter saginatur locunditate ciborum, ac tanto graviorem exhalat putrefacta foetorem, quanto suaviorem sibi procuravit educata mollitiem." (Reindel, 268).

23. Generelt kan hele den menneskelige forestillingsverden måske ses som værende genereret af et begrænset antal basic experiental structures, der i sig seiv er ganske simple, men som ved at repeteres i det uendelige danner tilsyneladende uoverskuelige og yderst komplicerede monstre og systemer, jf, de resultater, der foreligger fra forskning inden for kunstig intelligens (neurale netværk), kaos-teori og fraktal matematik.

\section{Litteratur}

Austin, John L., Philosophical Papers, Oxford 1961.

Blum, Owen J., The Letters of Peter Damian, The Fathers of the Church, Medieval Continuation, vol. 3, Washington D.C. 1992.

Cohn, Norman, The Pursuit of the Millenium, London 1962 (1957).

Dressler, Fridolin, "Petrus Damiani. Leben und Werke", Studia Anselmiana 34, 1954.

Gougaud, Louis, Dévotions et Pratiques Ascétiques du Moyen Age, Paris 1925.

Johnson, Mark, The Body in the Mind, Chicago 1987.

Lakoff, George Women, Fire and Dangerous Things. What Categories Reveal aboui the Mind, Chicago 1987.

Migne, J.-P., Patrologia Latina, LXVI, Paris 1847, 125-204. 


\title{
Oluf Schönbeck
}

Reindel, Kurt, "Die Briefe des Petrus Danianic, Monumenta Germaniae Historica, Die Briefe Der Deutschen Kaiserzeit, IV. Band, Teil 2, München 1988.

\begin{abstract}
Summary
"Notions of impurity in the monastic culture". A number of statements by the eleventh century ascetic Peter Damian concerning purity, impurity and purification are interpreted by means of the so-called Container Schema formulated by George Lakoff and Mark Johnson. According to Lakoff and Johnson humans experience their bodies as containers and as things in containers. Containers are characterized by the following structural elements: interior, boundary, exterior. Peter Damian is shown to describe impurity as a state of defilement, disease or bodily injury - all phenomena that are caused by a threatened or an actual breakdown of the boundary of the container, i.e. the human skin, the main purpose of which is to separate the interior from the menacing exterior. Basically then, impurity is seen as a result of an invasion of the body by foreign substances through the natural orifices, e.g. the senses, or through lesions - substances that may in their turn bring about unwanted discharges in the shape of e.g. semen or - in a metaphorical sense - sinful behaviour. Acts of purification are described by Damian in terms of the same container metaphor. Finally, it is suggested that the container metaphor may serve as a tool in analysing ideas of impurity outside a Christian, monastic context.
\end{abstract}

Oluf Schönbeck

Cand.phil, ph.d.-stipendiat

Institut for Religionshistorie

Kobenhavns Universitet 